\title{
GENDER DIFFERENCES IN APPROACH TO KNOWLEDGE AND CREATIVITY BY UNIVERSITY STUDENTS
}

\author{
Jana Marie Šafránková*, Klára Šimonová**
}

\begin{abstract}
Background. Background of the paper is based on human capital, who is the only stable source of competitive advantage for an organisation in knowledge and creative economy. The added value is created by people. Gender diversity is not sufficiently employed in the context of creativity.

Research aim. The paper is based on the authors' scientific research results and teaching experience, the research aim of the paper is to analyse different views on knowledge and creative competencies in the period of job preparation during university studies.
\end{abstract}

Methodology. The methodology employed is quantitative research and a case study of systematic and long-term observations of students' behaviour in creative case studies. The paper is looking for answers to three questions: Are there gender differences in the approach to accomplishment of tasks related to application of creativity? What is different in these approaches? What creative competencies are the most used and the most desired in organisation practice?

Key findings. Key findings from the research are revealed that there are certain variances, but weak; it seems that the main difference is coming from their personality. Gender differences apply to situations where it is convenient to use spatial abstract imagination (for men) or verbally addresing problems or specific objects (for women).

Keywords: creativity, gender, management, university students, research.

\footnotetext{
* Charles University in Prague, Czech Republic. E-mail: janamarie.safrankova@pedf.cuni.cz

** Czech Technical University in Prague, Czech Republic. E-mail: klara.simonova@cvut.cz
} 


\section{INTRODUCTION}

The end of the $20^{\text {th }}$ century and the beginning of $21^{\text {st }}$ century changed the perception of the human factor (Becker, 1993). In organisations and in their management, the demand on intellect and creativity of staff and managers has significantly augmented. In many work activities, not too creative repeating activities are interconnected with elements that require different levels of creativity. Only a small number of workers apply purely creative activities. Many will encounter varying degrees of creative approaches to work. Currently, the potential of an individual working in a project team and even with the awareness of gender differentiation is well explored. (Karwowski et al, 2016). Creativity is currently being investigated (when we consider routine work, both technical as well as social-oriented activities, not specific work activities such as artistic activities, architectural and design work, etc.) especially based on the work on various projects (Jin et al., 2016).

Concurrently, effective management is increasingly dependent on improving and mastering the techniques of mental activity. Contemporary management complexity multiplies the cost of management errors in the decision-making process while simultaneously increasing the role of intellect required for a scientific approach in dealing with new technology, change management, time management, crisis management, but also self-management of the executives themselves (Stephens \& Carmeli, 2016; Jablonski, 2014; Wong \& Neck, 2015). Present times require creativity and realisation of creative interaction between people. Creativity means a productive way of thinking reflected in human activities, while innovation is the actual implementation of creative ideas, which often results in a new product, service or process. The implementation of new ideas - innovation - is the main activity of creative management. Vision, strategy, goals and ideas are perceived as tools of creativity.

The aim of the paper is to analyse different views on knowledge and creative competencies in the period of job preparation during university studies. The methodology employed is quantitative research and a case study of systematic and long-term observations of students' behaviour in creative case studies. The paper is looking for answers to three questions: Are there gender differences in the approach to accomplishment of 
tasks related to application of creativity? What is different in these approaches? What creative competencies are the most used and the most desired in organisation practice?

\section{BACKGROUND}

Creativity means not only action, resulting in a new product, but also new approaches to solutions. Creativity thus means that through a creative process new solutions are found. The results of a creative process are usually perceived as something new for all, but the creative processes are also applied at an individual level. Creativity is a mental ability that is not easily measurable, is highly relative and certainly cannot be measured or captured by commonly used intelligence tests. Creativity is not dependent on intelligence, and even these terms are not used interchangeably, creativity is rather confused with flexibility. But paradoxically, very creative people tend to be very intelligent, as well as people with high self-actualisation needs (according to Maslow). J.P. Guilford tried to summarise and measure the factors that point to a relationship of intellect and creativity, concluding that there are ten different factors. Let us name e.g. verbal fluency (ability to remember vocabulary with specific characteristics), ideal fluency (ability to recall and enumerate things of certain categories, e.g. flowering houseplants), adaptive flexibility (ability to change the structure of shapes, e.g. puzzle relocation of matches), etc. The factors of creativity with no relationship to intellect are considered: e.g. high self-esteem, low level of conscientiousness, ambition, impulsivity, openness, tendency to conflict, and discontent (Nakonečný, 2009, pp. 216-224).

Demand for new concepts, products, and services increases the demand for creative people. In the opinion of experts on creative economy, the magic of creative collaboration lies in the fact that all team members will connect and take up evenly anywhere, anytime and utilize to the maximum extent of their individual potential and performance. (Baron \& Armstrong, 2007). Creative Management is a specific style of management and leadership in a creative process, the result of which is real solutions to decision problems. The key to creative management within the organisation is to increase efficiency and productivity while maintaining a required level of quality. 
Drucker (2015) states that creative managers, and they don't even have to be leaders in the modern sense of the word, adhere to the following eight principles:

- They ask, "What needs to be done?"

- They ask, "What is right for the enterprise?"

- They develop action plans.

- They take responsibility for decisions.

- They take responsibility for communicating.

- They are focused more on opportunities rather than problems.

- They run productive meetings.

- They think and say "we" rather than "I" (Drucker, 2015, p. 87).

On the basis of current knowledge, scientists constructed a model that includes the basic qualities of a creative personality that should be possessed by a creative manager. These characteristic features include:

- The ability to accept alternative solutions and to tolerate ambiguity. Just as there are no two exactly the same problems, equally there are no two same solutions to the same problem. Creativity requires having prepared several alternate solutions (scenarios) for the most serious decision problems.

- Stimulating freedom in decision making. Creative personalities, when they are assigned a task, do not look for restrictions that could occur, on the contrary, they cross borders, and therefore they find solutions that other people consider as unusual.

- Functional freedom, that fills up the space that the stimulating freedom has created. Managers, who are functionally free, do not perceive various individual items to be designed only for certain activities, but it can also be used in other ways.

- Flexibility. Creative managers do not insist on only the one and only right solution of a problem (though the solution seems acceptable). They do not mind leaving a solution formerly considered as the best, but now unsatisfactory (in the light of new possible solutions) and choose another option.

- The willingness to take risks. When making decisions under risk and uncertainty, especially in the phase of evaluation of options and finding the best optimal variant for implementation (the principle of optimisation), or in search of the first variant, which meets the defined criteria (the principle of satisfaction), the decision-maker's attitude to risk plays a significant role (Antušák, 2013, pp. 28-34). 
- Preference of chaos. Chaos management means influencing the current chaotic system, so that the regime of the chaotic system would come under periodic or non-periodic steady state. The true leader is the one who is able to navigate the pitfalls and unexpected developments on his/her risky and lonely managerial journey full of changes.

- Delayed satisfaction. Managers with a strongly developed sense for delayed gratification do not really expect that their ideas, solutions, and results would be accepted immediately. The sense of belonging to the whole process solutions is the greatest reward for them. The strain of a long-lasting effort contributes to creativity.

- Perseverance. Creative managers do not give up; on the contrary, they use failures as guidelines and incentives for further work. Any failure and obstacle must not be deterred because the creative managers are so much obsessed with achieving their goals.

- Courage. Many psychologists consider courage as the most important prerequisite for the success of a creative manager. Precisely because of barriers that get in the way of creative individuals and of the creative process, but also creativity as such, it is necessary that a truly creative manager is well-armed with a good dose of courage. They must face not only possible failures, but also the given status quo, the overall situation, that is not ready for a creative act yet (Žák, 2006, pp. 29-32). "The biggest obstacle to our knowledge is what we know, and not what we don't know" (Pokorný, 2006, p. 45).

\section{METHODOLOGY}

The main part of the paper presents the results of five years (2011-2016) of observation of behaviour and reactions of postgraduate and undergraduate students of the Czech Technical University in Prague (CTU). The described situations were included in seminars, when only one lecturer (second author of the paper) with part time students was present and irregularly two lecturers (both authors of the paper) with groups of full time students, observations are therefore not statistically accurate; this would require a second lecturer or observer to be always present and record the data, and the data would have to be determined by a metric. 
In our observation, we deal with estimated frequency without the ambition to statistically quantify the manifestations of creativity in the classroom. The observation was applied both to students of full-time study programs, usually aged 20-22 years, with a slight predominance of male students (about $60: 40$ ) and also to students of part-time studies, where the strongest group is men aged 25-28 years, but in the age group over 35 years, men absolutely outnumbered women, women are only an exception. The seminar is held every academic year in the summer semester with four teaching hours per week. The average of 80 students a year in full-time studies were divided into 4 groups (i.e. this part of the sample approximates to 400 students - in the year 2011 there were 75 students, in 2012 - 77 students, in 2013 - 85 students, in $2014-83$ students, in 2015 - 79, and in 2016 - 80 students). The group of parttime students always numbered 20 students a year in one group (i. e. this part of the sample draws up to 100 students; in that 85 male and 15 female). The whole sample hence verges on 500 students. Accurate numbers would depend on attendance of particular seminars. When there were two lecturers present, evidence was continuously taken and the notes on creativity of individual students were categorised after the seminars. At the end of the semester, students were acquainted with the results and their feedback was recorded. The results were continuously compared and the observation ended up after five years.

The next base of data, the comparison with approach of P. Drucker used as empirical background, are selected data of a longitudinal sociological research "Positions of CTU graduates on the labour market and its satisfaction" realised and conducted by Jana Šafránková in time period from 1996 to 2013 at the Czech Technical University in Prague (Šafránková, 1996-2013; Šafránková, Franěk, 2008). The survey was arranged by Šafránková, who set the methodology, questionnaire, sample, data analysis and conducted realisation with the help of students as interviewers and data processing. The questionnaire was approved by the management of the CTU. The data collection methods were surveys with a questionnaire of 64 questions, open, closed, and semi-closed; the methods of data analysis were mostly classification of first and second degree. The tools of surveys were focused on the description of graduates, their position on the Czech labour market, needed competition for receiving a good job position, feedback to the education system at the CTU, and it also contained the viewpoint of their employers. We only used a small part of results from year 2013 
with connection to creativity (Table 1). The numbers of respondents - CTU graduates used here equals 460 respondents. In the year 2013 there were 1,000 graduates from years 2008/09 and 2011/12 contacted, 460 answered. In academic year 2008/09 4,233 (Masters) graduates graduated from $8 \mathrm{CTU}$ faculties, the questionnaire was sent to 474 of them per percentage of graduates per faculty, 220 answered, 66\% men and 34\% women. In the academic year 2011/12 4,261 graduates graduated from 8 CTU faculties, the questionnaire was sent to 516 of them per percentage of graduates per faculty, 240 answered, $63 \%$ of men and $37 \%$ of women. The sampling error was $3.0 \%$. The research used the tools of descriptive statistics, including percentage and averages, pivot tables, the methods of comparison and deduction and Pearsons chi-square statistics at 5\% significance level for the verification of existence of the statistically significant differences in the individual responses. The calculation was made in statistical software SPSS and some parts were made in MS Excel.

The paper is looking for answer to three questions:

- Are there gender differences in the approach to the accomplishment of tasks related to the application of creativity, and there new approaches to solutions between gender different university students?

- What is different in these approaches?

- What creative competencies are the most used and the most desired in organisation practice?

\section{RESULTS}

\section{Observation of creativity of university students}

The following three examples describe situations that were originally intended as an exercise for other skills and activities of individuals in teams, but can be successfully used for illustration of a creative process, for identifying of creative personalities, to outline creative solutions etc.

\section{A ship}

This exercise is taken from the book Training of Social and Managerial Skills (Jarošová et al., 2005, 229), where it is included in a chapter 
dealing with management of work groups and teams. The basic idea of this exercise is to test the practical example of the division of team roles and to show that every collaboration also means a potential for a conflict. The challenge for a small group of four people is to draw a picture, e.g. under the slogan "In the team - we're all on the same boat" to draw a ship, while members of the group should not discuss, and each member must draw only with one colour marker that he/ she picked and cannot lend it to another member of the team. The lecturer intentionally does not set a time limit for completing the task. This publication also recommends using group discussion topics such as: Who first started painting - basic shapes or details? Which colour dominates, and may it mean something? Was there a conflict somewhere? Who is satisfied with the result and who is not and why?

And one of the possible uses is also the illustration of creativity (though we do not recommend at this particular exercise to discuss it with members of the participating groups):

- If we quit the work by a command too early (in the subjective perception of participants), it is possible to observe three possible reactions:

- aggression, reversal of anger against the lecturer,

- a quiet resignation and acceptance of subjectively perceived injustice without the will to fight back,

- creative excuses or justification of requests, why is it necessary to have the time limit extended.

There were no significant differences in the observed behaviour considering gender or age; only older students do not incline to aggressive reactions, contrary to younger students.

- Leaving too long time to complete the task and the lecturer showing no signs of interest in the results or solutions, then we can observe the following reactions:

- approximately $2 / 3$ of women consider the task to be fulfilled, and begin to focus on other activities, e.g. checking their mobile phone, checking the appearance, communication, etc., about $1 / 3$ of men is done as well and pulls out a cell phone; both men and women are expressing boredom, show no activity,

- $1 / 3$ of women devote to drawing details on the boat (passengers, fish in the sea, emblem on the flag, etc.), 1/3 of men devote to technical details (rudder, propeller, etc.), 
- the remaining third of the men begins to invent space utilisation (shading the ship, drawing fleet, oars, etc.), and only really the most creative individuals fold an origami steamship from the sheet of paper, possibly from another piece of paper fold one or more of origami steamers accompanying the original team boat, or cut out the top half of the boat and lodge a 3D image, but this applies only to totalling a maximum of $1 \%$ of men. Female students, according to our observations, are not creative in the use of space at all.

If a reward is available, it is advisable to use this exercise for demonstration of the connection of assigning tasks to assessment criteria. Students would be very surprised in the end if the lecturer assesses the images and on a basis of a made-up reason and appreciates one team (e.g. Team A was the fastest, or Team B drew a pirate parrot that amused us, or Team $\mathrm{C}$ showed an original creative outcome, therefore gets the reward). Here, again, different responses to assessment and ensuing reward are shown. If the reward is the scores and the other teams are in danger of not getting anything, then usually a sharp discussion is opened spontaneously about how unfair this situation is, and very few teams offer to rework the image according to the new criteria. If the reward is e.g. a bag of candies where there are enough candies for all, the reactions are different: the teams mutually praise, the winning team will voluntarily give up or share the reward respectively (each participant receives a piece of candy), and independently (or only with very little participation of the lecturer) would reach one of the basic management skills - how important it is to properly define the task to be performed, how important it is not to deviate from the performance assessment criteria, and how important it is for motivation to know about the reward already before completing the task.

This can be a part of a lecture and passed to students as an accomplished information, but if they go through this creative process when they find themselves the interconnections between the activities and they seek new challenges or problems themselves, then they fix the skill and remember it, and we can assume that it is easier to apply the knowledge to their own management practice. Needless to say, this exercise puts claim on both the friendly and cooperative atmosphere in the group, so as the creative individuals want to open and use their creative potential, and on the lecturer who should help create 
and maintain such an atmosphere, eventually to be able to work with emotions of the whole teams.

\section{Drawing a picture according to instructions}

This exercise is again originally focused on communication and assigning tasks. The group is split into two teams, the best to men and women, and compete in to what extent the result resembles the original. At first glance there is no creativity in this assignment, but on the contrary, during the exercise creative approaches can be encountered quite frequently. The task is simple: one team member obtains an image that the second team member has to draw on the blackboard. The picture must not be described as a whole, but only to instruct how to proceed when redrawing it. Thus, it is not possible to say e.g. that the picture is a house, but dealing differently, e.g. there is a horizontal line in the lower third, connected to two vertical lines, etc. Both members of the team, the one who draws and the one who instructs, best stand back to each other, so that the "instructor" believes that the "cartoonist" proceeds according to his/her instructions and so that the "cartoonist" is not corrected. We can say that teams of men are more successful when compared with the original outcome, particularly if it is an abstract or geometric pattern; but women are devising creative ways of presenting information, especially in cases with specific subjects.

Thus e.g. masculine approach: if the horizontal line length is one meter, then the vertical, which starts at $10 \mathrm{~cm}$ from the edge, measures $50 \mathrm{~cm}$; on the contrary, feminine approach: just a little bit, about the width of the palm, draw another line, shorter than the first one, about half of it. In the case of drawing birds and flowers, men are usually lost because it is demanding for them to invent different ways to describe the image, but women can handle it much easier. It is surprising that at this moment, even those men who had relatively good results in verbal fluency or spontaneous semantic flexibility (see intellectual factors of creativity above), are unable to enforce their skills, while women who did not score so well in measurable disciplines appeared to be more creative in practical use, respectively better able to achieve a result in practice. It should be noted that in this exercise we do not recommend to work with rewards, as it seems to be a barrier to creativity instead as a motivational factor, although the reasons for this behaviour are not clearly explainable respectively resulting from our observations. 


\section{Where does the Dane live?}

In this exercise focused on communication, information sharing, conducting work meetings, and again demonstrating of manifestations of individual team roles, we can just keep the basic structure, where participants in teams of six members (resp. five and one observer who provides feedback) get cards with pieces of information, while there is on one card also given the task to which the team has to come: to find answers to two questions. This is the classic variant of the game on adding information from elementary logic (a teacher lives next to a German; a lawyer lives in a white house; a tennis player drinks whiskey etc.) and the task is to connect nationality, profession, drink and hobby with colour of his house. Team members must not show the cards to each other, but they must share information only orally. The basis for this exercise is given in the aforementioned publication (Jarošová et al., 2005, p. 244). Here the combinatory and spatial abilities of men are demonstrated, but eventually organisation and communication abilities of women in the creative task solutions are revealed as an effective solution to this task. The most successful are the teams that are made up of both sexes with representation from all three basic groups of Belbin team roles (in this case the social action - thinking, preferably e.g. a team player who can stamp out potential conflicts; rather implementer than completer-finisher; and thinker are the perfect combination of roles).

Purely male and purely female teams are not so successful in the solution of this problem, if we measure the success in terms of time (fastest team $=$ successful). It is necessary to proceed creatively and systematically at the same time. Someone must summarise the information, derive new information and important consequences, someone has to move forward, respectively organise the process, someone has to carry out the instructions. Men tend in about $2 / 3$ of cases to draw houses, to move across the paper figurines they made, orient themselves in information intuitively, and if there is a problem and they are not successful, they tend to start over again from scratch, but applying practically the same procedure; while in about $2 / 3$ of cases it is the women in mixed teams, who, after several unsuccessful attempts to simple intuitive solution, draw a chart to record information and from which they subsequently emerge missing information. Women in purely female teams are not progressing so, it is surprising that they prefer to chat about possible ways of dealing with the problem, 
they support each other, they only rarely criticise each other's ideas, though they prove ineffective.

From our observations, however, it is not clear who contributes more to a solution, whether male or female, or which team member ultimately finds a way to the solution. This exercise can be further used to illustrate the difference in approach to creative solutions. If students are told in advance that the game is also used in the assessment/development centres, then they tend to be less creative, more pushing for a quick solution, an aggressive leader hives off. If the exercise is presented as a game, then the students do not follow time so much and are focused on development of creative and original approaches to the solution instead.

\section{Graduates opinions on creativity}

Table 1 presents partial results concerning the competencies of CTU graduates from the years 2008-2012, where also their employers were involved. The respondents (graduates) were asked on their perception of their level of particular competence, and their employers were asked to assess the desired level of competencies required for the job or for the employee respectively. Table 1 shows the difference in organisational practice - employers demand more creative competencies than graduates would expect.

The example of results of a small part of the study shows that the researched graduates have prerequisites for creative work and creative management, and that employers seek such competence in the graduates; and that all the selected competencies related to creativity are demanded by the employers, but not assumed to be really possessed by the graduates.

Table 1. Graduates' competencies with creativity (CTU 2008-2012, summary)

\begin{tabular}{|l|l|l|}
\hline Competencies (scale 10 - max., 1- min.) & Graduates & Employers \\
\hline General knowledge and insight & 6.29 & 6.36 \\
\hline Professional theoretical and methodological knowledge & 7.17 & 6.95 \\
\hline Ability to use expert knowledge in practice & 6.36 & 7.05 \\
\hline $\begin{array}{l}\text { Knowledge of the conditions for the use of expert } \\
\text { methods and theories in practice }\end{array}$ & 6.08 & 6.29 \\
\hline
\end{tabular}


Table 1. cont.

\begin{tabular}{|l|l|l|}
\hline Competencies (scale $10-$ max., 1 - min.) & Graduates & Employers \\
\hline Language skills in a foreign language & 4.24 & 5.97 \\
\hline Mathematical skills & 7.23 & 5.18 \\
\hline Computer skills & 6.54 & 6.87 \\
\hline Ability to work with information & 7.04 & 7.50 \\
\hline Skills to identify and solve problems & 6.47 & 7.73 \\
\hline Skills of creative and flexible thinking and acting & 6.26 & 7.35 \\
\hline Presentation skills and writing skills & 5.87 & 6.54 \\
\hline Independent decision-making skills & 5.97 & 6.57 \\
\hline Teamwork & 5.91 & 7.25 \\
\hline Ability to take responsibility & 5.56 & 7.13 \\
\hline Organisational and management skills to lead a team & 4.56 & 6.09 \\
\hline The ability to think and act economically/economic eligibility & 5.03 & 6.56 \\
\hline The ability to communicate with people, to negotiate & 5.05 & 7.16 \\
\hline Ability to adapt to changing circumstances, conditions & 5.95 & 7.14 \\
\hline $\begin{array}{l}\text { Ability to work in a multicultural / international environ- } \\
\text { ment }\end{array}$ & 4.72 & 5.98 \\
\hline Ability to train and organise own learning & 6.96 & 6.47 \\
\hline Technical competencies & 6.35 & 6.59 \\
\hline
\end{tabular}

Notes: The research used for evaluation of competencies indicator as a scale, when 10 is the maximum and 1 is the minimum. The authors are aware that in consequent comparisons there 2 methods of evaluation were used. For this level of interpretation, this approach is methodologically possible because the opinions of graduates and employers are compared.

Source: research CTU graduates 2013, J. Šafránková, own calculation.

\section{DISCUSSION \& CONCLUSIONS}

Currently the information and knowledge society needs the creativity of human resources for competitiveness. It is very important to develop creativity among students of all types of schools. The paper focused on analysing creativity among students of colleges and degree programs in economics and management. Human capital is the only stable source of 
competitive advantage for an organization. The added value is created by people. Gender diversity is not sufficiently employed in the context of creativity. There are gender differentiated limits in approach to social competencies and potential of human capital. Creativity means a productive way of thinking reflected in human activities, while innovation is the actual implementation of creative ideas, which often results in a new product, service or process. The implementation of new ideas - innovation - is the main activity of creative management.

The paper focused on a long-term, five-year survey among students performing creativity in project management situations. In this point of view, the paper was looking for answers to three research questions. Are there any gender differences in the approaches to the implementation of tasks related to the application of creativity, and are there new approaches to solutions between gender different university students? Our conclusion is "Yes, there are, but weak; it seems that the main difference is coming from their personality. Gender differences apply to situations where it is handy to use spatial abstract imagination (for men) or verbally addressing problems or specific objects (for women). However, the most successful are the teams that are made up of both sexes." The second research question was "What is different in these approaches?" Our findings from the observation and analysis of students' reaction in the process of creativity are that men use more imagination, while women their ability to communicate. The third research question was "What creative competencies are the most used and the most desired in organisation practice?" The results of our research and analyses of data are, that in organisational practice, we recommend to focus more on difference in typology of personality, for example with the help of Belbins' roles in project management, than to focus on gender differences as the main approach. The key findings of the research show that the prevailing differences in creativity between genders are more in personality than in the nature of gender. The second quoted survey, where the comparison between the opinions of CTU graduates and their employer was used, proves that even a quantitative survey demonstrates the fact that employers appreciate soft skills. When employers are asked to select key competencies for a good performance of work they prefer for their highly educated employees, they highlight soft skills associated with creative competences. Unfortunately, this research has not been done sorting graduates and their employers by gender. Moreover, all the selected 
competencies related to creativity are demanded by the employers, but not assumed to be really possessed by the graduates - employers demand more creative competencies than the graduates would expect.

\section{REFERENCES}

Antušák, E. (2013). Crisis readiness of the company. Praha: Wolters Kluwer.

Baron, A. \& Armstrong, M. (2007). Human Capital Management: Achieving Added Value through People. London \& Philadelphia: Kogan Page.

Becker, G.S. (1993). Human Capital. A Theoretical and Empirical Analysis with Special Reference to Education. Chicago \& London: The University Chicago Press.

Drucker, P. F: (2015). Effective leaders. Management Press, 2nd edition. Translation of the original: Effective Executive. The Definitive Guide to Getting the Right Things Done.

Jarošová, E., Komárková, R., Pauknerová, D. \& Pavlica, K. (2005). Trénink sociálních a manažerských dovedností. Metodický průvodce. Praha: Management Press.

Jablonski, A. (2014). The system and network in the processes of company value creation and destruction. International Journal of Contemporary Management, 13(4), 97-106. [Online] Retrieved from: http://8723.indexcopernicus. com/abstracted.php?level=4\&id_issue $=878261$.

Jin, X., Wang, L. \& Dong, H. (2016). The relationship between self-construal and creativity - Regulatory focus as moderator. Personality and Individual Differences, 97, 282-288. [Online] Retrieved from: http://www.elsevier.com/ locate/paid (access: 2016.02.01).

Karwowski, M., Dul, J., Gralewski, J., Jauk, E., Jankowska, D.M., Gajda, A., Chruszczewski, M.H. \& Benedek, M. (2016). Is creativity without intelligence possible? A Necessary Condition Analysis. Intelligence, (57), 105-117. [Online] Retrieved from: http://www.sciencedirect.com/science/journal/01602896/57 (access: 2016.03.26).

Nakonečný, M. (2009). Psychologie osobnosti. Praha: Academia.

Pokorný, J. (2006). Psychology consists of thinking. Prague: VSE.

Šafránková, J. (1996-2013). Positions of CTU graduates on the labour market. Sociological surveys. Praha: ČVUT.

Šafránková, J. \& Franěk, R. (2008). CTU students and graduates. Praha: ČVUT.

Stephens, J.P. \& Carmeli, A. (2016). The positive effect of expressing negative emotions on knowledge creation capability and performance of project teams. International Journal of Project Management 34, 862-873. 
Wong, P.S. \& Neck, P.A. (2015). When East meets West: A harmonised model for performance and institutional alignment to manage knowledge practitioners, their productivity in a knowledge based economy. International Journal of Contemporary Management, 14(1), 7-26. [Online] Retrieved from: http://8723. indexcopernicus.com/abstracted.php?level=4\&id_issue $=878261$ (access: 2016.01.15).

Žák, P. (2006). Creativity and its development. Praha: Computer Press. 


\title{
RÓŻNICE PKCI W PODEJŚCIU DO WIEDZY I KREATYWNOŚCI STUDENTÓW UCZELNI*
}

\begin{abstract}
Abstrakt
Tło badań. Tłem badań jest kapitał ludzki, który stanowi jedyne stabilne źródło przewagi konkurencyjnej w zakresie organizowania wiedzy i kreatywnej gospodarki. Wartość dodana jest tworzona przez ludzi. Różnorodność płci nie jest wystarczająco wykorzystywana w kontekście kreatywności.
\end{abstract}

Cel badań. Praca oparta jest na wynikach badań naukowych i doświadczeniu nauczycieli; celem badania jest analiza różnych poglądów na wiedzę i kompetencje twórcze w okresie przygotowania zawodowego w trakcie studiów uniwersyteckich.

Metodologia. Stosowana metodologia to badania ilościowe i studium przypadku systematycznych i długoterminowych obserwacji zachowań studentów w badaniach nad sytuacjami twórczymi. Praca szuka odpowiedzi na trzy pytania: czy w odniesieniu do płci istnieją różnice w podejściu do realizacji zadań związanych z zastosowaniem kreatywności? Co jest inne w tych podejściach? Jakie kompetencje twórcze sa najbardziej użyteczne i najbardziej pożądane w praktyce organizacyjnej?

Kluczowe wnioski. Kluczowe ustalenia z badań ujawniają że istnieja pewne wariancje, ale słabe. Wydaje się, że główną różnicę stanowi osobowość. Różnice w zakresie płci mają zastosowanie do sytuacji, w których dogodne jest użycie wyobraźni przestrzennej (dla mężczyzn) lub ustne rozwiązywanie problemów lub konkretnych obiektów (dla kobiet).

Słowa kluczowe: kreatywność, płeć, zarządzanie, studenci, badania naukowe.

* Acknowledgements: This paper was supported by the Internal Grants Agency of the College of Regional Development in Prague [IGA_Z8_02_2015 and IGA_Z9_02_2015]. 